\title{
Batch and Column Scale Removal of Cadmium from Water Using Raw and Acid Activated Wheat Straw Biochar
}

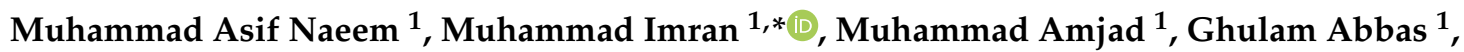 \\ Muhammad Tahir ${ }^{1}$, Behzad Murtaza ${ }^{1}$, Ali Zakir ${ }^{1}{ }^{\mathbb{D}}$, Muhammad Shahid $^{1}$, Laura Bulgariu ${ }^{2}$ and \\ Iftikhar Ahmad 1,*(D) \\ 1 Department of Environmental Sciences, COMSATS University Islamabad, Vehari Campus, \\ Vehari 61100, Pakistan \\ 2 Department of Environmental Engineering and Management, Technical University Gheorghe Asachi of Iasi, \\ 700050 Iasi, Romania \\ * Correspondence: imranrb@cuivehari.edu.pk (M.I.); iftikharahmad@cuivehari.edu.pk or \\ iffises@yahoo.com (I.A.)
}

Received: 8 May 2019; Accepted: 8 July 2019; Published: 12 July 2019

\begin{abstract}
The present study examined novel wheat straw biochar (WSB) and acid treated wheat straw biochar (AWSB) for cadmium removal from contaminated water. A series of batch and column scale experiments was conducted to evaluate the potential of WSB and AWSB for cadmium removal at different biochar dosage (0.5-8 g/L), initial cadmium concentration (5-100 mg/L), solution pH (2-8) and contact time (5-180 $\mathrm{min})$. Results revealed that cadmium adsorption decreased by increasing biochar dosage from 0.5 to $8 \mathrm{~g} / \mathrm{L}$; however, optimum dosage for maximum (99\%) removal of cadmium was $2 \mathrm{~g} / \mathrm{L}$ by WSB and $1 \mathrm{~g} / \mathrm{L}$ by AWSB. Enhanced cadmium removal potential by AWSB is attributed to increased surface area, microporosity and variation in functional groups. Equilibrium experimental data was well described by Freundlich adsorption isotherm whereas kinetic data were better explained with pseudo-second order model. Both WSB and AWSB have shown good adsorption capacity of $31.65 \mathrm{mg} / \mathrm{g}$ and $74.63 \mathrm{mg} / \mathrm{g}$, respectively, that is comparable with other costly adsorbents. Columns packed with WSB and AWSB at laboratory scale have also shown good retention of cadmium with excellent reusability. These findings indicate that WSB especially AWSB could be a promising, cost-effective and environmental friendly strategy for the removal of metals from contaminated water.
\end{abstract}

Keywords: activated biochar; column; sorption; kinetics; water treatment

\section{Introduction}

Cadmium $(\mathrm{Cd})$ is a non-essential heavy metal naturally occurring in geological formations. It enters the ecosystems through erosion and abrasion of rocks and soils. The beneficial use of $\mathrm{Cd}$ in the industry also contributes to environmental contamination with $\mathrm{Cd}$ as it can enter into the wastewater from industrial processes such as electroplating, Cd-Ni batteries, fertilizers, pesticides, ore mining, plastics, pigments, dyes, etc. Consumption of $\mathrm{Cd}$ containing food leads to its accumulation in living tissues causing various diseases and disorders. Hence, $\mathrm{Cd}$ must be removed from the wastewater before its disposal to the environment [1,2]. A variety of physical and chemical techniques is employed to remove metals, including $\mathrm{Cd}$ from contaminated water e.g., ion exchange, precipitation, flocculation/coagulation, adsorption, membrane filtration, evaporation and reverse osmosis etc. [2]. Most of these methods have limitations for metal removal due to sludge production, higher cost of energy and by-product formation [1,2]. However, the use of adsorbents for the removal of heavy metals has been increased in the last few years [3]. There are various adsorbents but carbon materials have 
been reported to be the best due to their numerous characteristics, are highly stable, have excellent removal efficiency and contain large surface area [4-6]. Wood and bark biochars have been used effectively as carbon materials to remove heavy metals from water e.g., arsenic (As), Cd and lead $(\mathrm{Pb})[7]$.

Recent literature shows that surface features of the biochar have been modified to enhance the adsorption potential, increase the number of functional groups and selectivity of biochar to remove several pollutants from polluted systems [8-10]. In addition, phosphate compound containing liquids such as phosphoric acid $\left(\mathrm{H}_{3} \mathrm{PO}_{4}\right)$ are known for their effectiveness in remediation of contaminated soils and also for the remediation of wastewater contaminated with heavy metals. The author of [11] reported that the addition of $\mathrm{PO}_{4}{ }^{3-}$ in wastewater results in numerous stabilization reactions. During these stabilization reactions, sorption of metals that are present in wastewater occur on particulate surfaces [12,13]. Furthermore, new surface metal precipitates, discrete heterogeneous and homogeneous metal precipitates are also formed. If biochar is modified with phosphate, it can be helpful to increase the ability of biochar to remove heavy metals by enhancing its sorption ability [13]. Phosphate modification can be very helpful for heavy metal removal but only few studies have been carried out in this regard.

The use of wheat straw biochar (WSB) has also been reported for the remediation of water contaminated with heavy metals and organic chemicals [14]. However, raw WSB may not be considered as a good material for the removal of heavy metals because of unavailability of sufficient functional groups as well as less surface area. The present study was carried out to evaluate the potential of WSB and WSB modified with $\mathrm{H}_{3} \mathrm{PO}_{4}$ to remove $\mathrm{Cd}$ from contaminated water. Adsorption capacities and $\mathrm{Cd}$ removal efficiencies of non-modified WSB and WSB modified with $\mathrm{H}_{3} \mathrm{PO}_{4}$ were compared after performing several batch experiments. To get insight into the microstructure and physical characteristics of both biochars (WSB and AWSB), multiple instrumental techniques including Fourier Transform Infrared spectroscopy (FTIR), Brunauer-Emmett-Teller (BET), Scanning electron microscopy (SEM) and X-ray diffraction (XRD) were used. The influence of adsorbent parameters such as residence time, solution $\mathrm{pH}$, adsorbent dosage and concentration of adsorbate $(\mathrm{Cd})$ are evaluated. Moreover, the adsorption capacity of WSB and AWSB was compared with the literature and experimental data were validated with equilibrium and kinetic sorption models.

\section{Materials and Methods}

\subsection{Preparation and Characterization of Biochar}

Wheat straw (WS) feedstock was obtained from the nearby farmer field $\left(30.02^{\circ} \mathrm{N}, 72.21^{\circ} \mathrm{E}\right)$ to prepare biochar. Feedstock was first dried in oven $\left(70^{\circ} \mathrm{C}\right)$ for $24 \mathrm{~h}$ and then was sieved through a $1 \mathrm{~mm}$ sieve). Biochar was prepared by a method described by [15] at $350{ }^{\circ} \mathrm{C}$ for $30 \mathrm{~min} @ 10{ }^{\circ} \mathrm{C} \min ^{-1}$. Acidified wheat straw biochar (AWSB) was prepared using physical activation method with second pyrolysis. The prepared biochar was mixed with a 30\% phosphoric acid $\left(\mathrm{H}_{3} \mathrm{PO}_{4}\right)$ for $24 \mathrm{~h}$ at 2:1 $\left(\mathrm{H}_{3} \mathrm{PO}_{4}\right.$ : biochar). The acid treated biochar was washed with deionized (DI) water and then dried at $70{ }^{\circ} \mathrm{C}$ in an oven for $24 \mathrm{~h}$. After oven drying, the activated biochar was pyrolyzed again in furnace under the same conditions as were used during the first pyrolysis.

A CHNS/O analyzer (2400 Series II, Perkin Elmer, Shelton, CT, USA) was used to find Carbon (C), hydrogen $(\mathrm{H})$, oxygen $(\mathrm{O})$ and sulfur $(\mathrm{S})$ content in WSB and AWSB with dry combustion. The concentrations of phosphorus $(\mathrm{P})$, potassium $(\mathrm{K})$, iron $(\mathrm{Fe})$, calcium $(\mathrm{Ca})$, magnesium $(\mathrm{Mg})$, sodium ( $\mathrm{Na}$ ) and $\mathrm{Cd}$ in both adsorbents were determined by digestion process as described by [16]. All the chemicals that have been used during the analysis were of analytical grade. Moisture content of the samples was measured on the basis of mass loss after drying samples at $105^{\circ} \mathrm{C}$, while volatile matter was calculated on heating the samples in covered crucible for $10 \mathrm{~min}$ at $950^{\circ} \mathrm{C}$. Ash content in the samples was found after drying the samples in open crucible at $750{ }^{\circ} \mathrm{C}$ until a constant mass was obtained. FTIR spectra on the surface of WSB and AWSB was determined in absorbance mode by forming 
pellets with $\mathrm{KI}$ or $\mathrm{KBr}$ powder using Matson Polaris IR spectrophotometer. Surface morphological characteristics of WSB and AWSB were found by scanning electron microscope (SEM) at 5 and $10 \mathrm{kV}$ with high magnification at $20 \mathrm{~mm}$ distance. Amorphous nature of WSB and AWSB was found using X-ray diffraction (XRD). While Brunauer-Emmett-Teller (BET, Tristar II 3020) was used to measure the BET surface area $\mathrm{S}_{\mathrm{BET}}$, total pore volume $\mathrm{Vt}$ and average pore diameter $\mathrm{D}_{\mathrm{p}}$.

\subsection{Measurement of Point of Zero Charge}

Point of zero charge (PZC) of WSB and AWSB was measured by using an electrolyte solution [17]. Electrolyte solution was prepared by using $\mathrm{NaCl}(0.1 \mathrm{M})$ in distilled water and separated in $250 \mathrm{~mL}$ conical flasks. The $\mathrm{pH}$ of the solution in flasks was maintained to 2, 4, 6 and 8 with $\mathrm{NaOH}$ and $\mathrm{HCl}$ solutions $(0.1 \mathrm{~N})$ with $\mathrm{pH}$ meter (Milwaukee $\mathrm{pH} 55$, Thailand). Dosage of $0.1 \mathrm{~g}$ of WSB and AWSB was added in each flask separately. As a control, four flasks of $\mathrm{pH}$ 2, 4, 6 and 8 were used without WSB and AWSB. All these flasks were shaken at $150 \mathrm{rpm}$ for $24 \mathrm{~h}$. After that, filtrate of the samples was obtained and their $\mathrm{pH}$ was measured. A graph was plotted between initial $\mathrm{pH}(2,4,6$ and 8$)$ and final $\mathrm{pH}$ after interaction of the material with electrolyte solution. The point of intersection of curve of the control and curve with WSB and AWSB $\mathrm{pH}$ gave PZC.

\subsection{Preparation of Synthetic Wastewater}

Analytical grade cadmium nitrate $\left(\mathrm{Cd}\left(\mathrm{NO}_{3}\right)_{2}\right.$; Merck) was used to prepare a stock solution of $\mathrm{Cd}$ $(1000 \mathrm{mg} / \mathrm{L})$ in distilled water. Stock solution was diluted to prepare the working solutions of different Cd concentrations $(5,10,25,50$ and $100 \mathrm{mg} / \mathrm{L})$.

\subsection{Batch Experiment}

A series of batch scale adsorption experiments for evaluating the affinity of adsorbents (WSB and AWSB) for Cd sorption was performed in duplicate sets in $250 \mathrm{~mL}$ conical flasks having $100 \mathrm{~mL}$ of Cd solution.

\subsubsection{Effect of Adsorbent Dose and $\mathrm{pH}$}

Effective (optimum) dosage of WSB and AWSB for the removal of Cd was found by changing their dosage from 0.5 to $8 \mathrm{~g} / \mathrm{L}$ keeping other parameters constant. A measured quantity of WSB and AWSB was taken in $100 \mathrm{~mL} \mathrm{Cd}$ solution at fixed $\mathrm{pH} 6$ and $\mathrm{Cd}$ concentration until equilibrium. Effective dose was chosen on the basis of Cd removal (\%) at different doses of WSB and AWSB. Impact of solution $\mathrm{pH}$ on $\mathrm{Cd}$ adsorption and removal was evaluated at $\mathrm{pH}(2-8)$ by keeping other factors such as initial concentration of $\mathrm{Cd}(25 \mathrm{mg} / \mathrm{L})$, WSB and AWSB dosage $2 \mathrm{~g} / \mathrm{L}$ and room temperature constant. Samples were agitated on a rotary shaker and were collected at equilibrium.

\subsubsection{Effect of Initial Cd Concentration and Time}

Adsorption capacity and metal removal (\%) by WSB and AWSB was determined at different initial concentrations of Cd (5-100 mg/L) at constant $\mathrm{pH}$ 6, WSB $(2 \mathrm{~g} / \mathrm{L})$ and AWSB $(1 \mathrm{~g} / \mathrm{L})$ at room temperature. Water samples were taken after 15, 30, 60, 90, 120 and $180 \mathrm{~min}$ until equilibrium was reached in the solution. Water samples were shaken at $150 \mathrm{rpm}$ with a mechanical shaker and centrifuged for $10 \mathrm{~min}$ at $3000 \mathrm{rpm}$. The samples were filtered with a Whatman filter paper $(0.45 \mu \mathrm{m})$. Residual concentration of $\mathrm{Cd}$ was measured in the filtrate with Atomic Absorption Spectrophotometer (AAS, PerkinElmer PinAAcle900F, Waltham, USA). The reliability of the Cd measurement was ensured by running standard solutions of $\mathrm{Cd}$ after every 15 samples. The calibration curve obtained with standard solutions of Cd using AAS had $\mathrm{R}^{2}=0.9998$. 


\subsubsection{Adsorption and Removal Analysis}

The mass of the $\mathrm{Cd}$ adsorbed per unit mass of the biochar $\left(q_{e}\right)(\mathrm{mg} / \mathrm{g})$ at equilibrium was calculated using Equation (1) from the initial concentration of $\mathrm{Cd}(\mathrm{mg} / \mathrm{L})$ in solution $C_{i}$, concentration of $\mathrm{Cd}$ ions at equilibrium $C_{e}$, dosage $W(\mathrm{~g})$ of WSB and AWSB, and volume $V$ of Cd containing solution (L) $[18,19]$.

$$
q_{e}=\left(\frac{C_{i}-C_{e}}{W}\right) \times V
$$

The removal of Cd ions $(R)$ by WSB and AWSB was estimated with Equation (2).

$$
R=\left(\frac{C_{i}-C_{f}}{C_{i}}\right) \times 100
$$

where $C_{i}$ and $C_{f}$ are the initial and final concentrations of $\mathrm{Cd}(\mathrm{mg} / \mathrm{L})$ in solution.

\subsubsection{Modeling Equilibrium Sorption Data}

Adsorption characteristics of WSB and AWSB were determined using four equilibrium adsorption isotherm models namely Langmuir, Freundlich, Temkin and Dubinin-Radushkevich. Langmuir isotherm model has been expressed in Equation (3) [19] and the values of adsorption parameters $K_{L}$ and $Q_{\max }$ were calculated from the intercept and slope of the curve between $\frac{C_{e}}{q_{e}}$ versus $C_{e}$ by using Equation (4):

$$
\begin{gathered}
q_{e}=\frac{K_{L} C_{e} Q_{\max }}{1+K_{L} C_{e}} \\
\frac{C_{e}}{q_{e}}=\frac{1}{K_{L} Q_{\max }}+\frac{1}{Q_{\max }} C_{e}
\end{gathered}
$$

where $Q_{\max }$ gives the highest adsorption of Cd by WSB and AWSB $(\mathrm{mg} / \mathrm{g}), K_{L}$ is a constant calculated from Langmuir mode (L/mg). Freundlich model has been empirically represented in Equation (5) [19].

$$
q_{e}=K_{F} C_{e}^{1 / n}
$$

In Equation (5), $q_{e}$ indicates the Cd adsorbed per unit mass of the WSB and AWSB at equilibrium $(\mathrm{mg} / \mathrm{g}), C_{e}$ is the residual $\mathrm{Cd}$ concentration at equilibrium $(\mathrm{mg} / \mathrm{L}), K_{F}$ is the Freundlich sorption constant and $n$ gives the adsorption intensity of WSB and AWSB. The values of Freundlich model parameters ( $n$ and $K_{F}$ ) were determined using linearized form of the model (Equation (6)) [19].

$$
\ln q_{e}=\ln K_{F}+\frac{1}{n} \ln C_{e}
$$

Other two models employed for equilibrium adsorption are Temkin (Equation (7)) and DubininRadushkevich (DR) models (Equation (8)).

$$
\begin{gathered}
q_{e}=B \ln A+B \ln C_{e} \quad \text { where } B=\frac{R T}{b} \\
\ln q_{e}=\ln q_{m}-k_{D R} \varepsilon^{2} \quad \text { where } \varepsilon=\left[R T \ln \left(1+\frac{1}{C_{e}}\right)\right]
\end{gathered}
$$

In Equation (7), $A$ and $B$ are Temkin isotherm constants (L/g) and sorption energy (J/mol), respectively. The $R$ is the gas constant $(\mathrm{J} / \mathrm{mol} / \mathrm{K}), b$ is the Temkin isotherm model constant linked to the energy parameter $B$. While $q_{m}$ indicates the theoretical sorption $(\mathrm{mg} / \mathrm{g}), k_{D R}$ is Dubinin-Radushkevich constant indicating mean sorption energy. The values of models parameters were found following [19]. The adsorption kinetics were evaluated with WSB $(0.2 \mathrm{~g})$ and AWSB $(0.1 \mathrm{~g})$ at Cd concentration of $50 \mathrm{mg} / \mathrm{L}$ and $\mathrm{pH}$ 6. The samples were taken in $10 \mathrm{~mL}$ plastic bottles at room temperature after 15, 30, 60, 90, 120 and $180 \mathrm{~min}$ of shaking. To validate the kinetic response of the Cd removal by both WSB 
and AWSB; pseudo-first order, pseudo-second order, intra-particle and Elovich models were employed (Equation 9) [20,21].

$$
\begin{array}{ll}
\log \left(q_{e}-q_{t}\right)=\log q_{e}-\frac{k_{1}}{2.303} t & \text { (Pseudo-first order) } \\
\frac{t}{q_{t}}=\frac{1}{k_{2} q_{e}^{2}}+\frac{t}{q_{t}} & \text { (Pseudo- sec ond order) } \\
q_{t}=k_{d i f} \sqrt{t}+C & \text { (Intra-particle diffusion) } \\
q_{t}=\frac{1}{\beta} \ln (\alpha \beta)+\frac{1}{\beta} \ln t & \text { (Elovich) }
\end{array}
$$

where $q_{e}$ stands for the simulated equilibrium adsorption $(\mathrm{mg} / \mathrm{g}), q_{e}$ is the kinetic adsorption at time $t$ (min), $k_{1}$ indicates the pseudo-first order adsorption rate constant $(1 / \mathrm{min}), k_{2}$ pseudo-second order adsorption rate constant $(\mathrm{g} / \mathrm{mg} / \mathrm{min}), k_{\text {dif }}$ indicates intra-particle diffusion constant $\left(\mathrm{mg} / \mathrm{g} / \mathrm{min}^{0.5}\right), C$ is a constant representing boundary layer thickness $(\mathrm{mg} / \mathrm{g}), \alpha$ is the initial adsorption rate $(\mathrm{mg} / \mathrm{g} / \mathrm{min})$ calculated in Elovich model and $\beta$ is the magnitude of the surface area covered by the Cd ions $(\mathrm{g} / \mathrm{mg})$.

\subsection{Laboratory Scale Column Experiments and Reusability of the Biochar}

Column experiments on laboratory scale were carried out at steady state in duplicate sets using plexiglass columns with the dimensions and arrangement given in Figure 1. About $5 \mathrm{~g}$ of WSB and AWSB was wet-packed separately as an interlayer between acid-cleaned quartz sand (0.2-0.5 mm) and gravel (2-2.5 mm) purchased from local market. After filling, the columns were initially flushed with distilled water for $1 \mathrm{~h}$. The experiment was carried out at four different initial concentrations of $\mathrm{Cd}(25,50$ and $100 \mathrm{mg} / \mathrm{L})$ at flow rate $2.1 \mathrm{~mL} / \mathrm{min}$ at $\mathrm{pH} 5$ (optimized in batch scale experiments). The effluent was collected after 10, 30, 60, 90, 120, 180, 240, 300, 330, 390, 600, 660, 720, 810, 900, 960, 1020 and 1080 min to determine the Cd concentration after retention of the contaminant at WSB and AWSB surface. The flow rate $(2.1 \mathrm{~mL} / \mathrm{min})$ at inlet and outlet sides was maintained with a peristaltic pump at each end. The acronyms $\mathrm{R} 1$ and $\mathrm{R} 2$ in Figure 1 represent replication one and replication two of the column experiments. To evaluate the reusability of WSB and AWSB, after each experimental run, the columns were flushed with $1 \% \mathrm{HCl}$ solution and then flushed with distilled water for $30 \mathrm{~min}$ before starting injection of the next concentration in columns.



Figure 1. Schematic representation of column scale experiments in laboratory for the removal of $\mathrm{Cd}$ from water using wheat straw biochar (WSB) and acid treated wheat straw biochar (AWSB). 


\section{Results and Discussion}

\subsection{Characterization of Biochars}

\subsubsection{Fourier Transform Infrared Spectra (FTIR)}

Various functional groups on the surface of biochars before and after the removal of $\mathrm{Cd}$ are shown in Figure 2A,B. The WSB and AWSB showed variation in absorbance peaks responsible for difference in $\mathrm{Cd}$ removal from the contaminated water. The area under absorbance peak in case of WSB was smaller as compared to AWSB. More hydroxyl functional groups $(-\mathrm{OH})$ were observed in WSB at 3600-3300 $\mathrm{cm}^{-1}$, while O-H stretching bands were less in AWSB.
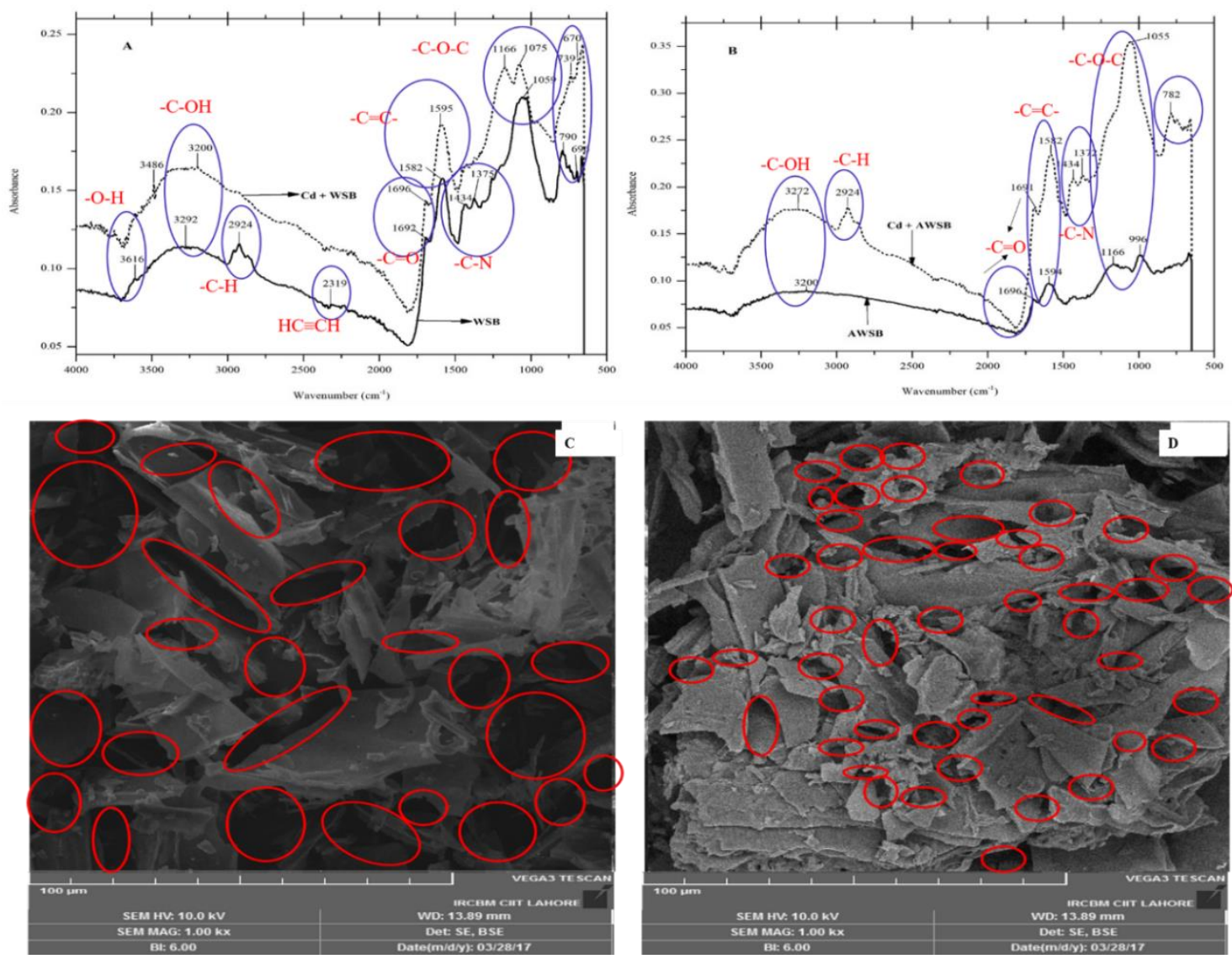

Figure 2. Fourier Transform Infrared (FTIR) spectra of Cd loaded and unloaded wheat straw biochar (WSB, (A)) and acid activated wheat straw biochar (AWSB, (B)); Scanning electron microscopy (SEM) images of WSB (C) and AWSB (D).

The results indicated that phosphoric acid $\left(\mathrm{H}_{3} \mathrm{PO}_{4}\right)$ worked as dehydrating agent and reacted with raw biochar (WSB) [22,23]. Addition of $\mathrm{H}_{3} \mathrm{PO}_{4}$ helped to reduce a substantial amount of hydrogen because asymmetric stretching of $\mathrm{C}-\mathrm{H}$ at $2924 \mathrm{~cm}^{-1}$ was observed in AWSB. This decline (171\%) in hydrogen content has also been observed in Table 1. Variation in absorbance peaks was observed in WSB after Cd adsorption, the peaks changed from $3616 \mathrm{~cm}^{-1}(-\mathrm{OH})$ to $3486 \mathrm{~cm}^{-1}$. The WSB did not show presence of aliphatic functional groups after $\mathrm{Cd}$ adsorption. However, the asymmetric $\mathrm{C}-\mathrm{H}$ stretching bands at $2940 \mathrm{~cm}^{-1}$ was observed in WSB before Cd adsorption, indicating the presence of aliphatic functional groups. Both of the WSB and AWSB showed presence of carboxyl groups and aromatic rings in the absorbance peaks attained at 1696 and $1585 \mathrm{~cm}^{-1}$, respectively [24,25]. Analysis of AWSB did not show the presence of C-H asymmetric at $1370 \mathrm{~cm}^{-1}$ and symmetric bending at $1440 \mathrm{~cm}^{-1}$ [23]. However, after sorption of $\mathrm{Cd}$, these bands were prevalent in AWSB. Presence of 
lactone and carbonyl groups was also observed at $1582 \mathrm{~cm}^{-1}$ in WSB, and at $1585 \mathrm{~cm}^{-1}$ in AWSB [26]. A decline in a series of very complex bands was observed in AWSB in the range of $1000-1260 \mathrm{~cm}^{-1}$.

Table 1. Various properties of wheat straw biochar (WSB) and acid wheat straw biochar (AWSB).

\begin{tabular}{ccc}
\hline Parameters & WSB & AWSB \\
\hline Moisture $\%$ & $5.83 \pm 0.18$ & $4.25 \pm 0.25$ \\
Volatile matters \% & $23.23 \pm 0.25$ & $41.50 \pm 0.50$ \\
Fixed carbon \% & $64.43 \pm 0.71$ & $44.30 \pm 0.50$ \\
Ash content \% & $12.50 \pm 0.50$ & $14.23 \pm 0.25$ \\
$\mathrm{C}(\mathrm{mg} / \mathrm{g})$ & $74.27 \pm 0.70$ & $68.23 \pm 0.55$ \\
$\mathrm{H}(\mathrm{mg} / \mathrm{g})$ & $5.90 \pm 0.18$ & $2.17 \pm 0.30$ \\
$\mathrm{O}(\mathrm{mg} / \mathrm{g})$ & $14.48 \pm 0.50$ & $25.50 \pm 0.50$ \\
$\mathrm{P}(\mathrm{mg} / \mathrm{g})$ & $0.54 \pm 0.11$ & $3.69 \pm 0.20$ \\
$\mathrm{~K}(\mathrm{mg} / \mathrm{g})$ & $10.43 \pm 0.25$ & $0.30 \pm 0.20$ \\
$\mathrm{Ca}(\mathrm{mg} / \mathrm{g})$ & $8.95 \pm 0.20$ & $3.82 \pm 0.20$ \\
$\mathrm{Mg}(\mathrm{mg} / \mathrm{g})$ & $4.01 \pm 0.20$ & $1.25 \pm 0.25$ \\
$\mathrm{~S}(\mathrm{mg} / \mathrm{g})$ & $0.63 \pm 0.13$ & $0.31 \pm 0.20$ \\
$\mathrm{Na}(\mathrm{mg} / \mathrm{g})$ & $0.97 \pm 0.13$ & $0.12 \pm 0.08$ \\
$\mathrm{Fe}(\mathrm{mg} / \mathrm{g})$ & $8.20 \pm 0.20$ & $6.24 \pm 0.25$ \\
$\mathrm{pH}$ & $7.95 \pm 0.10$ & $3.7 \pm 0.13$ \\
$\mathrm{~S}_{\mathrm{BET}}\left(\mathrm{m}^{2} / \mathrm{g}\right)$ & $207.33 \pm 12.01$ & $471.67 \pm 17.56$ \\
$\mathrm{~V}_{\mathrm{t}}\left(\mathrm{cm}^{3} / \mathrm{g}\right)$ & $0.12 \pm 0.04$ & $0.45 \pm 0.05$ \\
$\mathrm{D}_{\mathrm{p}}(\mathrm{nm})$ & $5.94 \pm 0.22$ & $11.25 \pm 0.25$ \\
\hline
\end{tabular}

Vibration of $(-\mathrm{OH})$ group can be observed at $3434 \mathrm{~cm}^{-1}$ in fiber sources and this vibration indicates the adsorption of metals present in contaminated water [1,2]. Presence of methyle and methylene groups (C-H) was observed at 2960 to $2924 \mathrm{~cm}^{-1}$ [27]. FTIR spectra showed that the functional groups such as alkane $(\mathrm{C}-\mathrm{H})$, carbonyls $(\mathrm{C}=\mathrm{O})$ and alcoholic $(-\mathrm{OH})$ observed on WSB and AWSB surface might have significantly contributed to the adsorption of $\mathrm{Cd}$ ions from contaminated water.

\subsubsection{Scanning Electron Microscopy (SEM) and BET Analysis}

The SEM results showed the surface morphology of WSB and AWSB (Figure 2C,D). It has been shown that thermal treatment of biochar resulted in increased graphitization effect and that probably could be due to the reason that biochar possessed turbostratic structure [28]. The activation of WSB with $\mathrm{H}_{3} \mathrm{PO}_{4}$ has changed the macro-pores into micro-pores that was observed on the surface of AWSB. Furthermore, the micro-pores were interlinked with meso-pores and this made it easy to access macro-pores present in inner surface, hence, showing larger surface area [29,30]. Acid treatment increased the area of AWSB $\left(471.67 \mathrm{~m}^{2} / \mathrm{g}\right)$ by 2.27 times as compared to the area of WSB $\left(207.33 \mathrm{~m}^{2} / \mathrm{g}\right)$. Furthermore, acid treated WSB also showed increased porosity and enhanced absorption capacity of biochar.

\subsubsection{XRD Analysis}

The XRD analysis showed the crystalline nature and revealed the structure of aromatic layers as indicated by the extremes at $2 \theta\left(20-30^{\circ}\right)$ (Figure $\left.3 \mathrm{~A}, \mathrm{~B}\right)$. Crystallites perpendicular to aromatic layers have small dimensions and broadening is the result of these small dimensions [31]. Existence of inorganic components such as crystalline $\mathrm{SiO}_{2}$ has been indicated by sharp and the strongest peak at $2 \theta=28.61^{\circ}$ [32]. XRD results showed that the surface of WSB and AWSB could be heterogeneous. 

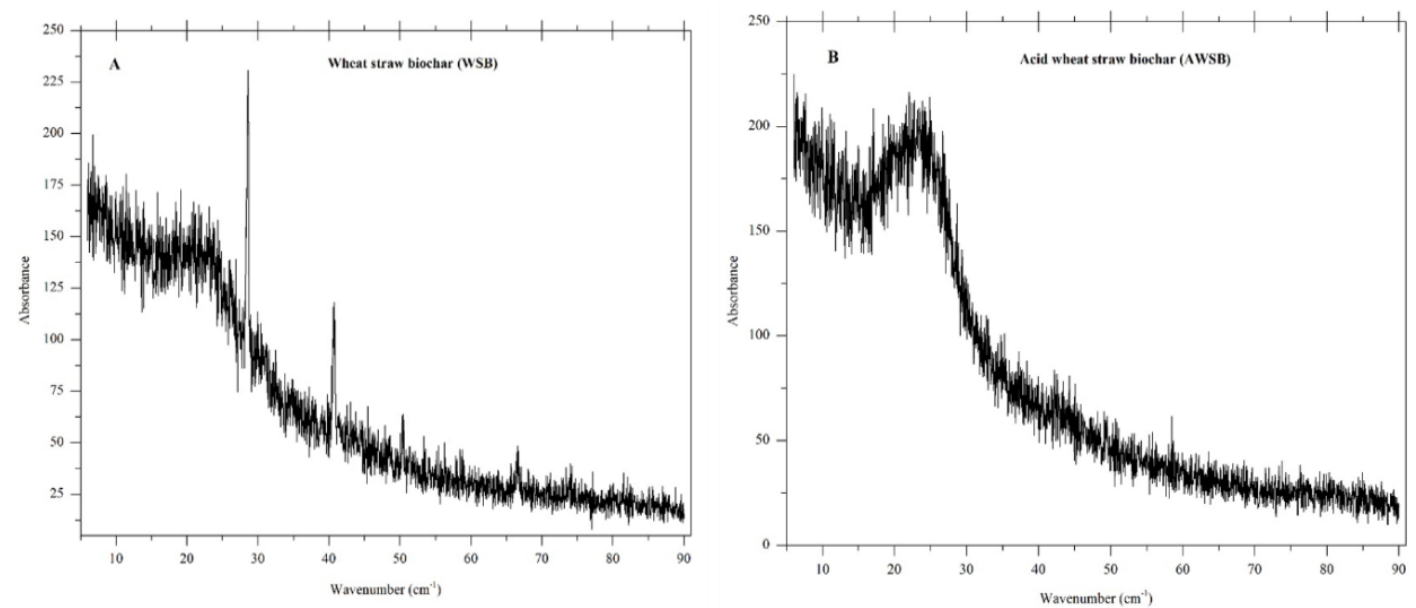

Figure 3. X-ray diffraction (XRD) patterns of wheat straw biochar (A) and acid activated wheat straw biochar (B) used for the removal of $\mathrm{Cd}$ from contaminated water.

\subsubsection{Elemental Analysis}

Elemental analysis for $\mathrm{C}, \mathrm{H}, \mathrm{O}, \mathrm{S}, \mathrm{P}, \mathrm{K}, \mathrm{Fe}, \mathrm{Ca}, \mathrm{Mg}, \mathrm{K}, \mathrm{S}, \mathrm{Na}$ and $\mathrm{Cd}$ in both WSB and AWSB was performed (Table 1). It has also been shown the volatile matter, moisture content, fixed carbon and ash carbon (Table 1).

\subsection{Measurement of PZC}

To evaluate the nature (acidity/basicity) of WSB and AWSB, PZC was measured with an electrolyte solution. It determined the $\mathrm{pH}$ where net surface charge of carbon material has been zero resulting from interaction between WSB, AWSB and electrolyte solution. The functional groups, protonation and deprotonation on the surface of WSB and AWSB influenced the determination of pHpzc. The pHpzc of the WSB was 5.3 and the pHpzc of the AWSB was 3.7. So, if $\mathrm{pH}$ has been less than $\mathrm{pHpzc}$, the surface of WSB and AWSB would be positively charged and if $\mathrm{pH}>\mathrm{pHpzc}$, then surface of WSB and AWSB would be negatively charged [33].

\subsection{Optimization for $\mathrm{Cd}$ Removal and Adsorption}

Adsorption has been influenced by many factors, such as $\mathrm{pH}$, dose of WSB and AWSB, shaking time and initial $\mathrm{Cd}$ concentration in aqueous solution. Therefore, these parameters were investigated to achieve optimum removal efficiency.

\subsubsection{Effect of Adsorbent Dosage and $\mathrm{pH}$}

One of the important factors controlling removal of contaminants from aqueous systems was dosage of the adsorbent material. Figure $4 \mathrm{~A}, \mathrm{~B}$ showed $\mathrm{Cd}$ adsorption $(\mathrm{mg} / \mathrm{g})$ and its removal $(\%)$ from $\mathrm{Cd}$ contaminated water, respectively. The maximum $\mathrm{Cd}$ was adsorbed at the dosage $0.5 \mathrm{~g} / \mathrm{L}$ of WSB and AWSB. The adsorption of Cd on biochar surface decreased with increase in dose of WSB and AWSB. The Cd adsorption on AWSB was higher $(60 \mathrm{mg} / \mathrm{g})$ as compared to adsorption on WSB $(40 \mathrm{mg} / \mathrm{g})$ at the dose of $0.5 \mathrm{~g} / \mathrm{L}$. In case of Cd removal (\%), the optimum dosage of WSB and AWSB was $2 \mathrm{~g} / \mathrm{L}$ and $1 \mathrm{~g} / \mathrm{L}$, respectively. The Cd removal by AWSB was higher than that of WSB. The removal increased from 61 to $86 \%$ for AWSB. However, the removal increased from $35 \%$ to $62 \%$ for WSB. The difference in $\mathrm{Cd}$ adsorbed on surface of biochar was more prominent when adsorbent mass added into $\mathrm{Cd}$ contaminated water was the lowest (i.e., 0.5 and $1 \mathrm{~g} / \mathrm{L}$ ). This difference was pronounced as the dose of adsorbent increased, for example from $2 \mathrm{~g} / \mathrm{L}$ to $8 \mathrm{~g} / \mathrm{L}$ (Figure 4B). However, at each adsorbent dose, the $\mathrm{Cd}$ removed from contaminated water was always less in WSB as compared to AWSB (Figure 4B). 

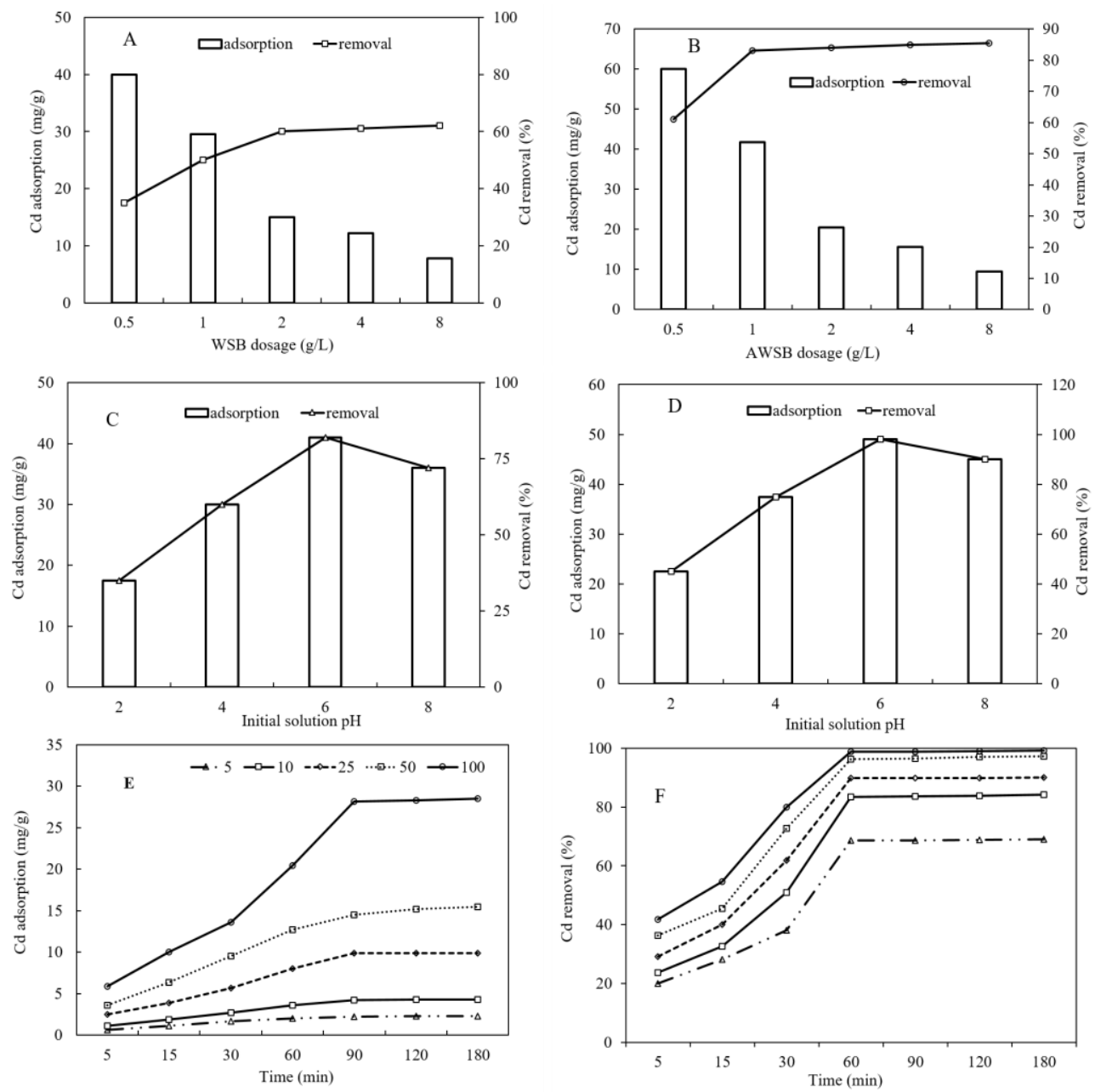

Figure 4. Adsorption and removal of $\mathrm{Cd}$ from contaminated water at different adsorbent dosage of wheat straw biochar (WSB; (A)) and acid activated wheat straw biochar (AWSB; (B)), solution pH of WSB (C), and AWSB (D); contact time (5-180 min; (E) and initial Cd concentrations of solution (5-100 mg/L; (F) amended with WSB (2 g/L) and AWSB (1 g/L).

The increment in the dosage of WSB and AWSB $(0.5$ to $8.0 \mathrm{~g} / \mathrm{L}$ ) resulted in decline of Cd adsorption; however, it increased Cd removal (Figure 4A,B). This happened because of larger surface area and higher number of adsorption sites [34-36]. The results showed that the increment in the dosage of WSB and AWSB enhanced the removal efficiency of Cd, but there was a decline in Cd sorption per unit mass. This decrease in $\mathrm{Cd}$ adsorption could be attributed to incomplete usage of adsorption sites or due to formation of aggregates in response to high adsorbent dosage $[19,37,38]$. The results of the present study are in complete agreement with literature [39], where adsorption of Cd decreased when adsorbent dose was increased. The difference in Cd removal with adsorbent WSB decreases after $2 \mathrm{~g}$ dose and in AWSB it decreased after $1 \mathrm{~g}$ dose. This may have happened because of the establishment of an equilibrium between WSB, AWSB and Cd concentration in the solution [40].

The $\mathrm{pH}$ of contaminated water also affects the adsorption of Cd by WSB and AWSB because it can change the charges present on the surface of WSB and AWSB thereby influencing the ionic strength of the solution [33]. The results showed that difference between WSB and AWSB in the $\mathrm{Cd}$ removal efficiency and adsorption capacity stays the same even after changing the $\mathrm{pH}$ of the solution (Figure 4C,D). But the adsorbent treated with phosphoric acid (AWSB) performed better for Cd remediation than WSB. The adsorption of $\mathrm{Cd}$ decreases with decrease in $\mathrm{pH}$, and the lowest adsorption was recorded when $\mathrm{pH}$ of solution was 2 . The adsorption of $\mathrm{Cd}$ and removal efficiency increased at higher $\mathrm{pH}$ of $\mathrm{Cd}$ contaminated water. Maximum $\mathrm{Cd}$ was removed at $\mathrm{pH} 6.0$ for both biochars (WSB 
and AWSB). However, adsorption capacity $(\mathrm{mg} / \mathrm{g})$ started to decrease when $\mathrm{pH}$ was changed from 6.0 to 8.0. Results revealed that the Cd removal efficiency improved from $35 \%$ to $82 \%$ when $\mathrm{pH}$ was varied from 2.0 to 6.0 for WSB. On the other hand, removal efficiency was more prominent in AWSB (45 to 98\%) when $\mathrm{pH}$ was changed from 2.0-6.0 while $\mathrm{Cd}$ adsorption by WSB enhanced from 16 to $41 \mathrm{mg} / \mathrm{g}$ when $\mathrm{pH}$ changed from 2.0-6.0. However, AWSB showed higher Cd adsorption (23-48 mg/g) than WSB.

This decline in adsorption efficiency at low $\mathrm{pH}$ may be attributed to the abundance of $\mathrm{H}^{+}$ions because they result in solid competition with $\mathrm{Cd}$ for the available adsorption sites of WSB and AWSB. However, adsorption capacity was improved with increase in $\mathrm{pH}$ due to the increased negative charges on biochars resulting from deprotonation of carboxylic and hydroxyl functional groups. Literature shows that adsorption of the heavy metals increases when there is an increase in solution $\mathrm{pH}[36,41,42]$. It may be credited to the reduced competition among protons and Cd ions to occupy the available sorption sites. Moreover, the number of binding sites is improved at higher $\mathrm{pH}$ leading to increase in total metal adsorbed on the adsorbent surface [36,42].

Moreover, $\mathrm{pH}$ effect on the $\mathrm{Cd}$ adsorption can be described from the results of $\mathrm{pH}_{\mathrm{pzc}}$ for both adsorbents (WSB and AWSB). The results of $\mathrm{pH}_{\mathrm{pzc}}$ showed that the $\mathrm{pH}_{\mathrm{pzc}}$ for WSB was higher (5.3) as compared with AWSB (3.7) (Figure 4C,D). If the $\mathrm{pH}<\mathrm{pH}_{\mathrm{pzc}}$ it can reduce Cd removal efficiency because of likely electrostatic repulsion among positively charged ions of $\mathrm{H}^{+}$and $\mathrm{Cd}$. Adsorption of $\mathrm{Cd}$ is enhanced when $\mathrm{pH}$ is increased because of electrostatic forces of attraction between surface of WSB and AWSB containing negative charges and positive Cd ions. The current study showed maximum removal of $\mathrm{Cd}$ at $\mathrm{pH}$, which is also applicable in the environment as most of the water resources have $\mathrm{pH}$ in the range $6-8$.

\subsubsection{Effect of Initial Cd Concentration and Contact Time}

Figure $4 \mathrm{E}, \mathrm{F}$ presents the effect of shaking time $(0-180 \mathrm{~min})$ on the amount of $\mathrm{Cd}$ adsorbed per unit mass of WSB and AWSB $\left(q_{t}\right)$ and removal at different Cd concentrations (10-100 mg/L). Comparison between AWSB and WSB revealed that AWSB showed maximum adsorption and removal of Cd ions in $60 \mathrm{~min}$, while WSB took $90 \mathrm{~min}$. The Cd adsorption by WSB changed from 2.3 to $28.2 \mathrm{mg} / \mathrm{g}$ after 90 min of shaking when Cd levels varied from 5 to $100 \mathrm{mg} / \mathrm{L}$, respectively. However, in case of AWSB at equilibrium, an increase in adsorption capacity (4.9 to $68.6 \mathrm{mg} / \mathrm{g}$ ) was observed, while the Cd removal decreased from $89.9 \%$ to $69 \%$. The adsorption process was of biphasic nature. Firstly, fast Cd adsorption was noticed within 90 min by WSB and 60 min by AWSB, following which the adsorption rate became slow due to equilibrium. The results revealed that $\mathrm{Cd}$ removal was relatively higher and adsorption capacity of both adsorbents showed decline when initial concentration of the Cd was increased. The results showed that AWSB performed better as compared with WSB for Cd removal from contaminated water. There was a slight variation in adsorption of Cd on AWSB (4 mg/g) and WSB $(2 \mathrm{mg} / \mathrm{g})$ at initial Cd level $5 \mathrm{mg} / \mathrm{L}$ while this difference was improved with increment in initial Cd levels. The results showed that $q_{t}$ for WSB was less $(20.5 \mathrm{mg} / \mathrm{g})$ than AWSB $(68.6 \mathrm{mg} / \mathrm{g})$ after $60 \mathrm{~min}$ of agitation at $100 \mathrm{mg} \mathrm{Cd} / \mathrm{L}$. A comparison between $\mathrm{Cd}$ removal by adsorbents at initial concentration (5 mg/L) showed that WSB removed 92\% Cd as compared with AWSB (99\%) (Figure 4E,F).

The presence of electrostatic field around the adsorbent was the main reason behind enhanced $\mathrm{Cd}$ adsorption when initial levels of $\mathrm{Cd}$ increased in the solution [43]. The adsorption of Cd on adsorbents was quicker at initial $\mathrm{Cd}$ concentration due to the fast adsorption process, which was associated with its activation energy [44]. After fast adsorption, the adsorption of $\mathrm{Cd}$ on adsorbents became slow because of the rearrangement of adsorbed $\mathrm{Cd}$ on the adsorbent surface, which caused better utilization of active adsorption sites.

\subsection{Cadmium Removal from Laboratory Scale Column Experiments and Reusability of The Biochar}

Figure 5 shows Cd removal $(\mathrm{a}, \mathrm{b})$ by WSB and AWSB, respectively, at three different initial concentrations of $\mathrm{Cd}(25,50$ and $100 \mathrm{mg} / \mathrm{L})$ in laboratory scale column experiments carried out 
with continuous injection of $\mathrm{Cd}$ contaminated water at steady state. These laboratory scale column experiments were carried out at fixed dosage, $\mathrm{pH}$, and temperature. The samples were collected from each column after 10, 30, 60, 90, 120, 180, 240, 300, 330, 390, 600, 660, 720, 810, 900, 960, 1020 and $1080 \mathrm{~min}$. The breakthrough curves for Cd removal show that maximum Cd was removed with AWSB in first 90 min when injected Cd concentration changed from $25-100 \mathrm{mg} / \mathrm{L}$ as compared with WSB.
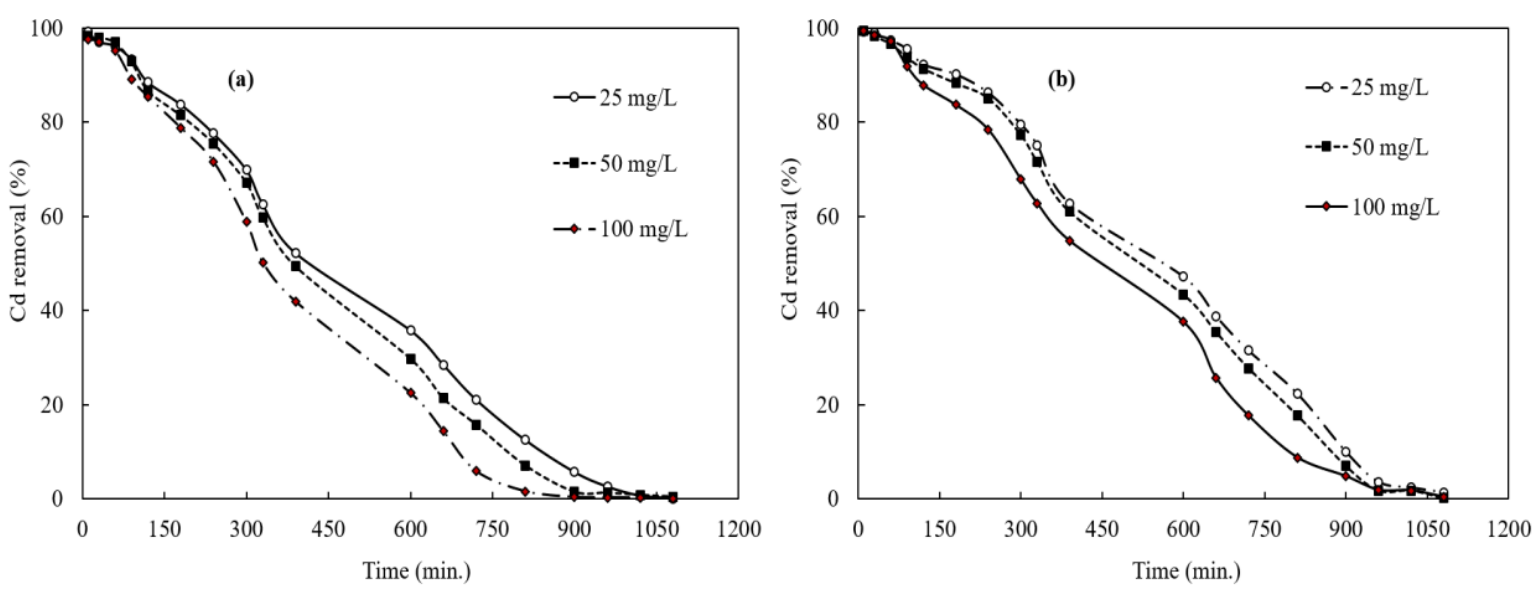

Figure 5. Removal of Cd at laboratory scale column experiments by WSB (a) and with AWSB (b) having different initial concentrations of Cd (25, 50 and $100 \mathrm{mg} / \mathrm{L})$ in response to WSB and AWSB dose (5 g/column).

Inlet concentration of contaminant is a significant factor affecting the performance of column experiments as it is the driving force for the transport of the adsorbate molecules towards the adsorbent surface [32,45]. In first $90 \mathrm{~min}, \mathrm{Cd}$ removal changed from $89.2-93.35 \%$ and $92.3-95.6 \%$, respectively by WSB and AWSB when Cd concentration varied from 100-25 mg/L. While after $240 \mathrm{~min}$, WSB showed $71.6-77.5 \%$ removal and $78.4-86.28 \% \mathrm{Cd}$ was removed by AWSB when initial concentration of $\mathrm{Cd}$ was varied from 100-25 mg/L. However, there was a decline in Cd removal with increase in initial concentration of $\mathrm{Cd}$ at a given time. The difference in $\mathrm{Cd}$ removal between 25 and $50 \mathrm{mg} / \mathrm{L}$ is less than the Cd removal between 50 and $100 \mathrm{mg} / \mathrm{L}$. This maximum removal of Cd by WSB and AWSB might be attributed to the dosage $(5 \mathrm{~g})$ and higher potential of WSB and AWSB due to the presence of different functional groups as shown in FTIR spectroscopy. The dosage or bed height of the adsorbent primarily affects the total uptake of a contaminant by the adsorbent [7,45]. At higher dosage (5 g/column) of WSB and AWSB, there is more contact of Cd with the adsorbents, which led to maximum removal of $\mathrm{Cd}$ at column scale. In future studies, column scale studies will be conducted to evaluate the effects of different process parameters: bed height, flow rate, temperature etc.

For reusability of WSB and AWSB, each column was flushed with $1 \% \mathrm{HCl}$ solution for $2 \mathrm{~h}$ to remove/desorb the $\mathrm{Cd}$ and then with distilled water for $30 \mathrm{~min}$ before injection of new concentration of Cd containing water. Over all, WSB and AWSB has excellent reusability for Cd removal.

\subsection{Study of Adsorption Isotherm Modeling}

Efficiency of Cd sorption on the surface of WSB and AWSB was studied using adsorption isotherm models. It was found that Freundlich isotherm model better explained the Cd equilibrium sorption data with WSB and AWSB due to heterogeneous surface as compared with other isotherms (Langmuir, Temkin and Dubinin-Radushkevich) (Table 2). The $\mathrm{R}^{2}$ of isotherm plots were $>0.98$ with Freundlich model. Furthermore, activation of WSB with acid improved adsorption characteristics of biochar surface because of heterogeneous surface as confirmed with SEM. The linear plots with Temkin and Dubinin-Radushkevich yielded less $\mathrm{R}^{2}$ (0.68-0.87) indicating less suitability (Table 2). Hence, the highest adsorption of WSB and AWSB illustrated from Langmuir model were 31.65 and $74.63 \mathrm{mg} / \mathrm{g}$, respectively. Moreover, it was also higher than activated carbons produced by using wood and bark as 
feedstock material $(0.34-5.40 \mathrm{mg} / \mathrm{g})$ [7] and activated carbons available for sale in markets $(8.00 \mathrm{mg} / \mathrm{g})$. Furthermore, biochars derived from pig and cow manure yielded $Q_{\max }$ ranging from 78.2 to $118 \mathrm{mg} / \mathrm{g}$ [41].

Table 2. Parameters of adsorption isotherm models at constant temperature (room temperature), $\mathrm{pH} 6$ and optimum dose of WSB $($ dosage $=2 \mathrm{~g} / \mathrm{L})$ and AWSB $($ dosage $=1 \mathrm{~g} / \mathrm{L})$.

\begin{tabular}{ccccccccccccccc}
\hline Models & \multicolumn{3}{c}{ Langmuir } & \multicolumn{3}{c}{ Freundlich } & \multicolumn{3}{c}{ Temkin } & \multicolumn{3}{c}{ Dubinin-Radushkevich } \\
\hline Parameters & $K_{L}$ & $Q_{\max }$ & $R^{2}$ & $K_{F}$ & $n$ & $R^{2}$ & $K_{T}$ & $B$ & $R^{2}$ & $q_{m}$ & $k_{D R}$ & $E$ & $R^{2}$ \\
\hline WSB & 0.871 & 31.65 & 0.849 & 3.46 & 1.87 & 0.982 & 1.92 & 478.3 & 0.856 & 13.33 & 0.247 & 1.4 & 0.694 \\
AWSB & 0.271 & 74.63 & 0.967 & 15.95 & 2.37 & 0.996 & 12.55 & 255.9 & 0.870 & 32.79 & 0.038 & 3.6 & 0.689 \\
\hline
\end{tabular}

The values of $n$ are important to show whether the adsorbent materials are appropriate for $\mathrm{Cd}$ adsorption. In our case, the values of $n$ showed that WSB and AWSB favored the Cd adsorption. The Cd sorption potential of AWSB was approximately four times the WSB as inferred from the values of $K_{F}, 15.95$ and 3.46, respectively. Specifically, $K_{F}$ values improved considerably for AWSB, probably as a result of the increased surface area (Table 1$)$. It resulted in a higher concentration gradient driven movement of Cd ions into pore spaces of AWSB (Figure 2C,D). Considerably, greater Freundlich adsorption constant $\left(K_{F}\right)$ values obtained with AWSB suggest its efficient application for the removal of $\mathrm{Cd}$ ions from contaminated water.

\subsection{Adsorption Kinetics of $\mathrm{Cd}$}

In the present work, pseudo-first order, pseudo-second order, intra-particle diffusion and Elovich kinetic models were used to describe the kinetic adsorption of Cd onto WSB and AWSB. The parameters calculated for $\mathrm{Cd}$ adsorption by using kinetic models are presented in Table 3. The coefficient of determination $\left(\mathrm{R}^{2}\right)$ in kinetic studies showed that $\mathrm{Cd}$ adsorption fitted well with pseudo-second order kinetic model rather than pseudo-first order, intra-particle diffusion and Elovich kinetic models. Furthermore, second-order kinetic model gave maximum correlation coefficients $\left(R^{2}=0.978-0.997\right)$ indicating possible chemisorption of the Cd onto surface of adsorbents (WSB and AWSB) [46,47]. The results showed that $q_{e}$ values of pseudo-second order kinetic model with AWSB and WSB were $34.84 \mathrm{mg} / \mathrm{g}$ and $16.18 \mathrm{mg} / \mathrm{g}$, respectively. It is reported that the second order kinetic model can easily describe details about metals retained on biochar and activated carbon [48]. In the present study, results indicate that chemisorption might be the rate controlling mechanism, suggesting possible sharing of electrons between Cd ions and WSB and AWSB [36].

Table 3. Parameters of kinetic models at initial Cd concentration $(25 \mathrm{mg} / \mathrm{L})$, constant temperature (room temperature), $\mathrm{pH} 6$ and optimum dose of WSB (dosage $=2 \mathrm{~g} / \mathrm{L}$ ) and AWSB (dosage $=1 \mathrm{~g} / \mathrm{L}$ ).

\begin{tabular}{ccccccccccccc}
\hline Models & \multicolumn{4}{c}{ Pseudo-First Order } & \multicolumn{2}{c}{ Pseudo-Second Order } & \multicolumn{2}{c}{ Intra-Particle Diffusion } & \multicolumn{3}{c}{ Elovich } \\
\hline Parameters & $k_{1}$ & $q_{e}$ & $R^{2}$ & $k_{2}$ & $q_{e}$ & $R^{2}$ & $k_{\text {dif }}$ & $C$ & $R^{2}$ & $\alpha$ & $\beta$ & $R^{2}$ \\
\hline WSB & 0.239 & 11.95 & 0.803 & 0.0025 & 16.18 & 0.987 & 0.545 & 5.54 & 0.725 & 4.49 & 0.658 & 0.879 \\
AWSB & 0.514 & 26.38 & 0.743 & 0.0030 & 34.84 & 0.996 & 1.10 & 15.38 & 0.550 & 5.05 & 0.356 & 0.725 \\
\hline
\end{tabular}

\subsection{Comparison of $\mathrm{Cd}$ Sorption Capacity with Other Adsorbents}

The Cd adsorption on WSB and AWSB (mg/g) was compared with different adsorbents used in previous studies for the $\mathrm{Cd}$ removal (Table 4). The adsorption capacities reported by other researchers varied greatly among different adsorbents. The reason behind this variation can be different chemical composition and surface characteristics, particle size and presence of certain functional groups [21,49]. In the present work, the biochar was prepared with wheat straw, which contains significant amounts of lignin (24.1\%), cellulose (32.6\%) and hemicellulose (22.2\%) [50]. This was the reason that the biochar produced with crop straws e.g., WS possessed high surface area and more developed pore spaces in comparison with other feed stock materials [51]. This characteristic along with other properties such 
as heterogeneous surface, existence of carbon-oxygen functional group, made WSB an adsorbent of choice as compared with other adsorbents. Furthermore, the pyrolysis and addition of phosphoric acid further enhanced the adsorption capacity of WSB because of the modifications in surface characteristics of the adsorbent (functional groups). It is reported that biochar produced with ligno-cellulosic material as a feedstock adsorbed metal with the help of chemical charged groups (e.g., amino and carboxylic etc.). It is attributed to the enhanced metal sorption of AWSB as compared with WSB due to the surface modification with phosphoric acid.

Table 4. Comparative analysis of sorption capacity $(\mathrm{mg} / \mathrm{g})$ of various plant-based biochars.

\begin{tabular}{ccc}
\hline Feedstock & $Q_{\max }$ & Reference \\
\hline Water hyacinth & 70.30 & {$[11]$} \\
KOH activated Cassava stem & 24.88 & {$[30]$} \\
Cassava stem & 10.46 & {$[30]$} \\
Peanut shells & 32.00 & {$[37]$} \\
Phosphate modified activated bamboo & 202.55 & {$[52]$} \\
Bamboo & 24.95 & {$[52]$} \\
Canna indica & 188.80 & {$[53]$} \\
Ipomoea fistulosa & $41.67-72.43$ & {$[54]$} \\
Dairy manure & 54.60 & {$[55]$} \\
Eichornia Crassipes & 49.84 & {$[56]$} \\
Wheat straw & 45.00 & {$[57]$} \\
Grape husk & 29.20 & {$[57]$} \\
Rice straw & 34.13 & {$[58]$} \\
Buffalo weed & 11.63 & {$[59]$} \\
Wheat straw & $31.65-74.63$ & Present study \\
\hline
\end{tabular}

\section{Conclusions}

The results revealed that the surface modification of biochar significantly improved the surface properties, thereby improving performance for $\mathrm{Cd}$ removal. Therefore, more $\mathrm{Cd}(99 \%)$ was removed with AWSB from water as compared with WSB. The Cd removal was improved at higher dosage of each sorbent (WSB and AWSB) from 0.5 to $8 \mathrm{~g} / \mathrm{L}$. However, the optimum dose of WSB and AWSB for $\mathrm{Cd}$ removal was $2 \mathrm{~g} / \mathrm{L}$ and $1.0 \mathrm{~g} / \mathrm{L}$, respectively. Removal of $\mathrm{Cd}$ changed from $56-90 \%$ and $70-99 \%$ with WSB and AWSB, respectively, when initial concentration of Cd varied from 100-5 mg/L. The maximum $\mathrm{Cd}$ was removed at $\mathrm{pH} 6$ with both WSB and AWSB. The adsorption experimental data obtained with WSB and AWSB adsorbents fitted well with Freundlich isotherm as compared with Langmuir, Temkin and Dubinin-Radushkevich models. The increased Cd removal efficiency from $69 \%$ to $99 \%$ with acid treatment is accredited to the enhanced BET surface area and removal of impurities from particles surface with acid, thereby changing functional groups on AWSB. The experimental kinetic data was well described with pseudo-second order kinetic model in comparison with pseudo-first order, intra-particle diffusion and Elovich models. Laboratory scale column experiments showed excellent retention of Cd with WSB and AWSB even at $100 \mathrm{mg} \mathrm{Cd} / \mathrm{L}$. This study concluded that activated wheat straw biochar is a cost-effective adsorbent for $\mathrm{Cd}$ removal from wastewater and have the potential for the removal of organic and inorganic pollutants.

Author Contributions: M.A.N., M.I. and I.A. conceptualized the project design; M.A.N., M.A. prepared biochar and executed work; G.A., M.T. and B.M. performed characterization; M.I. and A.Z. performed modeling on the data, M.S. and L.B. contributed in the final draft of the manuscript. All authors contributed to the review and edit process. M.I. and I.A. submit and review the manuscript.

Funding: This study was part of the project "SRGP Grant Number 1001" funded by the Higher Education Commission of Pakistan (HEC).

Acknowledgments: We are thankful to the Higher Education Commission of Pakistan (HEC) for the financial support of the current research work under SRGP. We are also thankful to the anonymous reviewers for their positive criticism on this manuscript. 
Conflicts of Interest: The authors declare no conflict of interest.

\section{References}

1. Rao, K.; Mohapatra, M.; Anand, S.; Venkateswarlu, P. Review on cadmium removal from aqueous solutions. Int. J. Eng. Sci. Technol. 2010, 2, 81-103. [CrossRef]

2. Haris, M.R.; Wahab, N.A.; Reng, C.W.; Azahari, B.; Sathasivam, K. The sorption of cadmium (II) ions on mercerized rice husk and activated carbon. Turk. J. Chem. 2011, 35, 939-950.

3. Sawalha, M.F.; Peralta-Videa, J.R.; Romero-González, J.; Gardea-Torresdey, J.L. Biosorption of Cd (II), Cr (III), and $\mathrm{Cr}(\mathrm{VI})$ by saltbush (Atriplex canescens) biomass: Thermodynamic and isotherm studies. J. Colloid Interface Sci. 2006, 300, 100-104. [CrossRef] [PubMed]

4. Chandra, V.; Park, J.; Chun, Y.; Lee, J.W.; Hwang, I.-C.; Kim, K.S. Water-Dispersible Magnetite-Reduced Graphene Oxide Composites for Arsenic Removal. ACS Nano 2010, 4, 3979-3986. [CrossRef] [PubMed]

5. Hanigan, D.; Zhang, J.; Herckes, P.; Krasner, S.W.; Chen, C.; Westerhoff, P. Adsorption ofNNitrosodimethylamine Precursors by Powdered and Granular Activated Carbon. Environ. Sci. Technol. 2012, 46, 12630-12639. [CrossRef] [PubMed]

6. Zhang, Y.; Min, Q.; Wang, W.; He, L.; Zheng, J. Impact of household social-economic characteristics on the willingness to grow crops: A case study of jasmine growers in Fuzhou based on conservation of the agricultural heritage system. Zhongguo Shengtai Nongye Xuebao/Chin. J. Eco-Agric. 2016, 24, 1714-1721.

7. Mohan, D.; Pittman, C.U.; Bricka, M.; Smith, F.; Yancey, B.; Mohammad, J.; Steele, P.H.; Alexandre-Franco, M.F.; Gómez-Serrano, V.; Gong, H.; et al. Sorption of arsenic, cadmium, and lead by chars produced from fast pyrolysis of wood and bark during bio-oil production. J. Colloid Interface Sci. 2007, 310, 57-73. [CrossRef] [PubMed]

8. Chen, J.P.; Wu, S.; Chong, K.-H. Surface modification of a granular activated carbon by citric acid for enhancement of copper adsorption. Carbon 2003, 41, 1979-1986. [CrossRef]

9. Rivera-Utrilla, J.; Sánchez-Polo, M.; Gómez-Serrano, V.; Álvarez, P.; Alvim-Ferraz, M.; Dias, J.M.; José, R.-U.; Alvarez, P.; Alvim-Ferraz, M.D.C. Activated carbon modifications to enhance its water treatment applications. An overview. J. Hazard. Mater. 2011, 187, 1-23. [CrossRef] [PubMed]

10. Ma, Y.; Liu, W.-J.; Zhang, N.; Li, Y.-S.; Jiang, H.; Sheng, G.-P. Polyethylenimine modified biochar adsorbent for hexavalent chromium removal from the aqueous solution. Bioresour. Technol. 2014, 169, 403-408. [CrossRef] [PubMed]

11. Zhang, F.; Wang, X.; Yin, D.; Peng, B.; Tan, C.; Liu, Y.; Tan, X.; Wu, S. Efficiency and mechanisms of Cd removal from aqueous solution by biochar derived from water hyacinth (Eichornia crassipes). J. Environ. Manag. 2015, 153, 68-73. [CrossRef] [PubMed]

12. Crannell, B.S.; Eighmy, T.T.; Krzanowski, J.E.; Eusden, J.D., Jr.; Shaw, E.L.; Francis, C.A. Heavy metal stabilization in municipal solid waste combustion bottom ash using soluble phosphate. Waste Manag. 2000, 20, 135-148. [CrossRef]

13. Seshadri, B.; Bolan, N.; Choppala, G.; Kunhikrishnan, A.; Sanderson, P.; Wang, H.; Currie, L.; Tsang, D.C.; Ok, Y.; Kim, G.; et al. Potential value of phosphate compounds in enhancing immobilization and reducing bioavailability of mixed heavy metal contaminants in shooting range soil. Chemosphere 2017, 184, 197-206. [CrossRef] [PubMed]

14. Saleh, T.A.; Sulaiman, K.O.; Al-Hammadi, S.A.; Dafalla, H.; Danmaliki, G.I. Adsorptive desulfurization of thiophene, benzothiophene and dibenzothiophene over activated carbon manganese oxide nanocomposite: With column system evaluation. J. Clean. Prod. 2017, 154, 401-412. [CrossRef]

15. Sánchez, M.; Lindao, E.; Margaleff, D.; Martínez, O.; Morán, A. Pyrolysis of agricultural residues from rape and sunflowers: Production and characterization of bio-fuels and biochar soil management. J. Anal. Appl. Pyrolysis 2009, 85, 142-144. [CrossRef]

16. Lima, I.M.; Boykin, D.L.; Klasson, K.T.; Uchimiya, M. Influence of post-treatment strategies on the properties of activated chars from broiler manure. Chemosphere 2014, 95, 96-104. [CrossRef] [PubMed]

17. Aliabadi, H.M.; Saberikhah, E.; Pirbazari, A.E.; Khakpour, R.; Alipour, H. Triethoxysilylpropylamine modified alkali treated wheat straw: An efficient adsorbent for methyl orange adsorption. Cellul. Chem. Technol. 2018, 52, 129-140. 
18. Edokpayi, J.N.; Odiyo, J.O.; Msagati, T.A.M.; Popoola, E.O. A Novel Approach for the Removal of Lead(II) Ion from Wastewater Using Mucilaginous Leaves of Diceriocaryum eriocarpum Plant. Sustainability 2015, 7, 14026-14041. [CrossRef]

19. Imran, M.; Suddique, M.; Shah, G.M.; Ahmad, I.; Murtaza, B.; Shah, N.S.; Mubeen, M.; Ahmad, S.; Zakir, A.; Schotting, R.J. Kinetic and equilibrium studies for cadmium biosorption from contaminated water using Cassia fistula biomass. Int. J. Environ. Sci. Technol. 2018, 16, 3099-3108. [CrossRef]

20. Babarinde, A.; Onyiaocha, G.O. Equilibrium sorption of divalent metal ions onto groundnut (Arachis hypogaea) shell: Kinetics, isotherm and thermodynamics. Chem. Int. 2016, 2, 37-46.

21. Shah, G.M.; Nasir, M.; Imran, M.; Bakhat, H.F.; Rabbani, F.; Sajjad, M.; Farooq, A.B.U.; Ahmad, S.; Song, L.; Eroglu, E. Biosorption potential of natural, pyrolysed and acid-assisted pyrolysed sugarcane bagasse for the removal of lead from contaminated water. PeerJ 2018, 6, e5672. [CrossRef] [PubMed]

22. Hesas, R.H.; Arami-Niya, A.; Daud, W.M.; Sahu, J.N. Preparation and Characterization of Activated Carbon from Apple Waste by Microwave-Assisted Phosphoric Acid Activation: Application in Methylene Blue Adsorption. BioResources 2013, 8, 2950-2966.

23. Suárez-García, F.; Martínez-Alonso, A.; Tascón, J. Pyrolysis of apple pulp: Effect of operation conditions and chemical additives. J. Anal. Appl. Pyrolysis 2002, 62, 93-109. [CrossRef]

24. Regmi, P.; Moscoso, J.L.G.; Kumar, S.; Cao, X.; Mao, J.; Schafran, G. Removal of copper and cadmium from aqueous solution using switchgrass biochar produced via hydrothermal carbonization process. J. Environ. Manag. 2012, 109, 61-69. [CrossRef] [PubMed]

25. Jiang, Y.; Huo, X.; Zhu, Y.; Ji, H. Chemisorption and Physical Adsorption Roles in Cadmium Biosorption by Chlamydomonas Reinhardtii. Chin. J. Popul. Resour. Environ. 2010, 8, 54-58.

26. Deng, Y.; Huang, S.; Laird, D.A.; Wang, X.; Dong, C. Quantitative mechanisms of cadmium adsorption on rice straw- and swine manure-derived biochars. Environ. Sci. Pollut. Res. 2018, 25, 32418-32432. [CrossRef] [PubMed]

27. Tangjuank, S.; Insuk, N.; Tontrakoon, J.; Udeye, V. Adsorption of lead (II) and cadmium (II) ions from aqueous solutions by adsorption on activated carbon prepared from cashew nut shells. World Acad. Sci. Eng. Technol. 2009, 52, 110-116.

28. Keiluweit, M.; Nico, P.S.; Johnson, M.G.; Kleber, M. Dynamic Molecular Structure of Plant Biomass-Derived Black Carbon (Biochar). Environ. Sci. Technol. 2010, 44, 1247-1253. [CrossRef]

29. Azargohar, R.; Dalai, A. Steam and $\mathrm{KOH}$ activation of biochar: Experimental and modeling studies. Microporous Mesoporous Mater. 2008, 110, 413-421. [CrossRef]

30. Prapagdee, S.; Piyatiratitivorakul, S.; Petsom, A. Activation of Cassava Stem Biochar by Physico-Chemical Method for Stimulating Cadmium Removal Efficiency from Aqueous Solution. Environ. Asia 2014, 7, 60-69.

31. Takagi, H.; Maruyama, K.; Yoshizawa, N.; Yamada, Y.; Sato, Y. XRD analysis of carbon stacking structure in coal during heat treatment. Fuel 2004, 83, 2427-2433. [CrossRef]

32. Liu, Y.; Zhao, X.; Li, J.; Ma, D.; Han, R. Characterization of bio-char from pyrolysis of wheat straw and its evaluation on methylene blue adsorption. Desalin. Water Treat. 2012, 46, 115-123. [CrossRef]

33. Al-Degs, Y.; Elbarghouthi, M.; Elsheikh, A.; Walker, G. Effect of solution pH, ionic strength, and temperature on adsorption behavior of reactive dyes on activated carbon. Dye. Pigment. 2008, 77, 16-23. [CrossRef]

34. Chen, X.; Chen, G.; Chen, L.; Chen, Y.; Lehmann, J.; McBride, M.B.; Hay, A.G. Adsorption of copper and zinc by biochars produced from pyrolysis of hardwood and corn straw in aqueous solution. Bioresour. Technol. 2011, 102, 8877-8884. [CrossRef]

35. Chen, Z.; Liu, T.; Tang, J.; Zheng, Z.; Wang, H.; Shao, Q.; Chen, G.; Li, Z.; Chen, Y.; Zhu, J.; et al. Characteristics and mechanisms of cadmium adsorption from aqueous solution using lotus seedpod-derived biochar at two pyrolytic temperatures. Environ. Sci. Pollut. Res. 2018, 25, 11854-11866. [CrossRef] [PubMed]

36. Usman, A.; Sallam, A.; Zhang, M.; Vithanage, M.; Ahmad, M.; Al-Farraj, A.; Ok, Y.S.; Abduljabbar, A.; Al-Wabel, M. Sorption process of date palm biochar for aqueous Cd (II) removal: Efficiency and mechanisms. Water Air Soil Pollut. 2016, 227, 449. [CrossRef]

37. Ahmad, M.; Lee, S.S.; Dou, X.; Mohan, D.; Sung, J.-K.; Yang, J.E.; Ok, Y.S. Effects of pyrolysis temperature on soybean stover-and peanut shell-derived biochar properties and TCE adsorption in water. Bioresour. Technol. 2012, 118, 536-544. [CrossRef] 
38. Ahmad, M.; Moon, D.H.; Vithanage, M.; Koutsospyros, A.; Lee, S.S.; Yang, J.E.; Lee, S.E.; Jeon, C.; Ok, Y.S. Production and use of biochar from buffalo-weed (Ambrosia trifida L.) for trichloroethylene removal from water. J. Chem. Technol. Biotechnol. 2014, 89, 150-157. [CrossRef]

39. Ahmad, I.; Akhtar, M.J.; Jadoon, I.B.K.; Imran, M.; Ali, S. Equilibrium modeling of cadmium biosorption from aqueous solution by compost. Environ. Sci. Pollut. Res. 2017, 24, 5277-5284. [CrossRef]

40. Boudrahem, F.; Soualah, A.; Aissani-Benissad, F. Pb(II) and Cd(II) Removal from Aqueous Solutions Using Activated Carbon Developed from Coffee Residue Activated with Phosphoric Acid and Zinc Chloride. J. Chem. Eng. Data 2011, 56, 1946-1955. [CrossRef]

41. Kołodyńska, D.; Wnetrzak, R.; Leahy, J.J.; Hayes, M.; Kwapinski, W.; Hubicki, Z. Kinetic and adsorptive characterization of biochar in metal ions removal. Chem. Eng. J. 2012, 197, 295-305. [CrossRef]

42. Sallam, A.S.; Al-Omran, A.; El-Naggar, A.H.; Nadeem, M.; Al-Wabel, M.I.; Usman, A.R.; Alenazi, K.K. Chemically Modified Biochar Produced from Conocarpus Wastes: An Efficient Sorbent for Fe(II) Removal from Acidic Aqueous Solutions. Adsorpt. Sci. Technol. 2013, 31, 625-640.

43. Jiang, K.; Sun, T.-H.; Sun, L.-N.; Li, H.-B. Adsorption characteristics of copper, lead, zinc and cadmium ions by tourmaline. J. Environ. Sci. 2006, 18, 1221-1225. [CrossRef]

44. Guo, Z.; Liu, X.; Huang, H. Kinetics and Thermodynamics of Reserpine Adsorption onto Strong Acidic Cationic Exchange Fiber. PLoS ONE 2015, 10, e0138619. [CrossRef] [PubMed]

45. Ge, X.; Wu, Z.; Manzoli, M.; Jicsinszky, L.; Wu, Z.; Nosyrev, A.E.; Cravotto, G. Adsorptive Recovery of Iopamidol from Aqueous Solution and Parallel Reuse of Activated Carbon: Batch and Flow Study. Ind. Eng. Chem. Res. 2019, 58, 7284-7295. [CrossRef]

46. Kim, W.-K.; Shim, T.; Kim, Y.-S.; Hyun, S.; Ryu, C.; Park, Y.-K.; Jung, J. Characterization of cadmium removal from aqueous solution by biochar produced from a giant Miscanthus at different pyrolytic temperatures. Bioresour. Technol. 2013, 138, 266-270. [CrossRef]

47. Lu, H.; Zhang, W.; Yang, Y.; Huang, X.; Wang, S.; Qiu, R. Relative distribution of $\mathrm{Pb}^{2+}$ sorption mechanisms by sludge-derived biochar. Water Res. 2012, 46, 854-862. [CrossRef]

48. Inyang, M.; Gao, B.; Yao, Y.; Xue, Y.; Zimmerman, A.R.; Pullammanappallil, P.; Cao, X. Removal of heavy metals from aqueous solution by biochars derived from anaerobically digested biomass. Bioresour. Technol. 2012, 110, 50-56. [CrossRef]

49. Salam, O.E.A.; Reiad, N.A.; Elshafei, M.M. A study of the removal characteristics of heavy metals from wastewater by low-cost adsorbents. J. Adv. Res. 2011, 2, 297-303. [CrossRef]

50. Guo, W.; Xiong, W.; Gao, S.; Hu, Z.; Liu, H.; Yu, R. Impact of temperature on the isothermal adsorption/ desorption of shale gas. Pet. Explor. Dev. 2013, 40, 514-519. [CrossRef]

51. Sun, Y.; Gao, B.; Yao, Y.; Fang, J.; Zhang, M.; Zhou, Y.; Chen, H.; Yang, L. Effects of feedstock type, production method, and pyrolysis temperature on biochar and hydrochar properties. Chem. Eng. J. 2014, 240, 574-578. [CrossRef]

52. Zhang, S.; Zhang, H.; Cai, J.; Zhang, X.; Zhang, J.; Shao, J. Evaluation and Prediction of Cadmium Removal from Aqueous Solution by Phosphate-Modified Activated Bamboo Biochar. Energy Fuels 2017, 32, 4469-4477. [CrossRef]

53. Cui, X.; Fang, S.; Yao, Y.; Li, T.; Ni, Q.; Yang, X.; He, Z. Potential mechanisms of cadmium removal from aqueous solution by Canna indica derived biochar. Sci. Total. Environ. 2016, 562, 517-525. [CrossRef] [PubMed]

54. Goswami, R.; Shim, J.; Deka, S.; Kumari, D.; Kataki, R.; Kumar, M. Characterization of cadmium removal from aqueous solution by biochar produced from Ipomoea fistulosa at different pyrolytic temperatures. Ecol. Eng. 2016, 97, 444-451. [CrossRef]

55. Xu, X.; Cao, X.; Zhao, L.; Wang, H.; Yu, H.; Gao, B. Removal of Cu, Zn, and Cd from aqueous solutions by the dairy manure-derived biochar. Environ. Sci. Pollut. Res. 2013, 20, 358-368. [CrossRef] [PubMed]

56. Li, F.; Shen, K.; Long, X.; Wen, J.; Xie, X.; Zeng, X.; Liang, Y.; Wei, Y.; Lin, Z.; Huang, W.; et al. Preparation and Characterization of Biochars from Eichornia crassipes for Cadmium Removal in Aqueous Solutions. PLoS ONE 2016, 11, 0148132. [CrossRef] [PubMed]

57. Trakal, L.; Bingöl, D.; Pohořelý, M.; Hruška, M.; Komárek, M. Geochemical and spectroscopic investigations of $\mathrm{Cd}$ and $\mathrm{Pb}$ sorption mechanisms on contrasting biochars: Engineering implications. Bioresour. Technol. 2014, 171, 442-451. [CrossRef] [PubMed] 
58. Han, X.; Liang, C.-F.; Li, T.-Q.; Wang, K.; Huang, H.-G.; Yang, X.-E. Simultaneous removal of cadmium and sulfamethoxazole from aqueous solution by rice straw biochar. J. Zhejiang Univ. Sci. B 2013, 14, 640-649. [CrossRef] [PubMed]

59. Yakkala, K.; Yu, M.-R.; Roh, H.; Yang, J.-K.; Chang, Y.-Y. Buffalo weed (Ambrosia trifida L. var. trifida) biochar for cadmium (II) and lead (II) adsorption in single and mixed system. Desalin. Water Treat. 2013, 51, 7732-7745. [CrossRef]

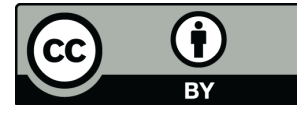

(C) 2019 by the authors. Licensee MDPI, Basel, Switzerland. This article is an open access article distributed under the terms and conditions of the Creative Commons Attribution (CC BY) license (http://creativecommons.org/licenses/by/4.0/). 